\title{
Changes in concentration of serum prolactin during social and reproductive development of the spotted hyaena (Crocuta crocuta)
}

\author{
A. S. van Jaarsveld, A. A. McKenzie and J. D. Skinner \\ Mammal Research Institute, University of Pretoria, Pretoria 0002, South Africa
}

\begin{abstract}
Summary. A homologous radioimmunoassay system developed for humans was used to measure prolactin concentrations in spotted hyaenas. Concentrations of prolactin showed a significant $(P<0.05)$ decrease in lactating females, which is consistent with the infrequent suckling pattern of this species. This lack of hyperprolactinaemic conditions during lactation may explain the ability of females to resume reproductive activity soon after the loss of a litter, or even during lactation. Prolactin concentrations did not increase significantly during dispersion in male spotted hyaenas. This conforms to the pattern observed for cortisol, but differs from that for androgen, which fluctuates significantly with social suppression. Although comparative data from other species provide some circumstantial evidence for hyperprolactinaemic conditions during male dispersal, no obvious deductions regarding the recorded inverse relationship between prolactin and cortisol concentrations in mature males could be made.
\end{abstract}

Keywords: prolactin; spotted hyaena; lactation; dispersal

\section{Introduction}

The social unit, or clan, of the spotted hyaena (Crocuta crocuta) comprises a variable number of closely related matrilocal lineages (Mills, 1985; Frank, 1986; Henschel \& Skinner, 1987) and a multimale group that consists of males in various stages of immigration or emigration (Frank, 1986; Henschel \& Skinner, 1987). Females are generally philopatric and remain in their natal clans to breed; males tend to disperse at about puberty and join neighbouring clans, where they may have opportunities to mate. This emigration is not without risk, as the acceptance of a male into a new clan may take up to several months, during which time antagonistic encounters with members of the target clan can result in death (Kruuk, 1972; Henschel \& Skinner, 1987). Females are generally the dominant social class, followed by their female cubs and then resident natal males that have not yet dispersed, central immigrant or mating males and peripheral immigrant males that are in the process of dispersing (Henschel \& Skinner, 1987). This social structure results in the social suppression of concentrations of androgen in plasma of most males, with only the central immigrant males that have been accepted into a target clan having increased androgen titres (van Jaarsveld \& Skinner, 1991a).

Spotted hyaenas are considered the only precocial fissiped carnivores (van Jaarsveld et al., 1988). They usually produce two young, which are dependent on milk for 4-6 months and are not weaned until 14-18 months old (East et al., 1989). Although this extensive lactation period suggests a low potential for population recruitment (Henschel, 1986), females can resume breeding soon after the loss of a litter, through either death or weaning (Grimpe, 1916; Golding, 1969; Henschel \& Skinner, 1990) and even while still lactating (Schneider, 1926; Kruuk, 1972). Histological evidence as well as changes in concentrations of plasma progesterone and oestradiol suggest that some follicular development may occur during lactation in this species (van Jaarsveld et al., 1992). This 
provides a mechanism whereby reproductive activity may be initiated during lactation or soon after the loss of a litter in this aseasonal breeder (Lindeque \& Skinner, 1982).

This investigation evaluated the roles played by prolactin as a stress related hormone (Drago et al., 1989) during male dispersal and as a hormone involved in regulating ovarian activity during lactation in most mammals (McNeilly, 1987).

\section{Materials and Methods}

\section{Animals}

Twenty-eight spotted hyaenas ( $>$ I year old) with established social histories were sampled between 1984 and 1987 from (a) the Mavumbye and Shingkelengane clans that are resident in the central district of the Kruger National Park, South Africa $\left(24^{\circ} 20^{\prime} \mathrm{S}, 31^{\circ} 45^{\prime} \mathrm{E}\right)$ (Henschel \& Skinner, 1987, 1989), (b) the Letaba clan $\left(23^{\circ} 56^{\prime} \mathrm{S}, 31^{\circ} 40^{\prime} \mathrm{E}\right)$ resident around the Letaba Rest Camp in the Kruger National Park and (c) the Kousant clan that lives on the boundary between the Kalahari Gemsbok National Park (South Africa) and the Gemsbok National Park (Botswana) $\left(25^{\prime \prime} 15^{\prime} \mathrm{S}, 20^{\circ} 30^{\prime} \mathrm{E}\right)$. This clan is the subject of a long-term project on behavioural ecology (Mills, 1985).

In addition, 12 cubs ( $\leqslant 1$ year old) were sampled from various localities in the Kruger National Park and from the National Zoological Gardens (Pretoria) in South Africa. This was an effective way of increasing the sample size for the younger age group, as they do not disperse before attaining reproductive maturity (Kruuk, 1972; Frank, 1983; Mills, 1985; Henschel \& Skinner, 1987).

Animals were grouped into one of the following social categories, according to Henschel \& Skinner (1987): female cuos ( $\leqslant 1$ year), resident females ( $>1$ year), male cubs ( $\leqslant 1$ year), resident natal males, peripheral immigrant males or central immigrant males. Reproductive status was assessed through external examination according to the criteria specified by Matthews (1939) and animals were grouped as belonging to one of the following reproductive categories: nulliparous female, parous female, lactating female, immature male ( $\leqslant 2$ years) and mature males ( $>2$ years). Ages of animals of unknown age were estimated from the height and surface area of the mandibular premolar $\left(\mathrm{PM}_{3}\right)$ (van Jaarsveld et al., 1987).

Free-ranging and captive hyaenas were immobilized with Zoletil (about $4 \mathrm{mg} \mathrm{kg}^{-1}$ body weight, CI-744: Anchorpharm Pty Ltd, Bramley, S. Africa) following van Jaarsveld (1988). As all animals were the subjects of longterm field studies or in captivity, they were habituated to vehicles and human disturbance. The only stressors they were subjected to were therefore the mild response to the sting of the small air-powered dart $(1 \mathrm{ml}$; Telinject S.A., Randburg, S. Africa) and the subsequent loss of consciousness owing to the anaesthetic effects of Zoletil. The behaviour of animals strongly suggested that the darting was not a traumatic experience, whereas the loss of consciousness was. Extended anaesthesia $(90 \mathrm{~min})$ for serial blood sampling was achieved by administering halothane (Fluothane: ICI Pharmaceuticals Ltd, Johannesburg, S. Africa) using a circle absorber machine. Induction was achieved with a $10 \%$ mixture of halothane in oxygen and the animals were maintained using $2-4 \%$ halothane in a closed circuit. This method was preferred as it provided a more stable plane of anaesthesia than other immobilizing chemicals. Clinical procedures followed van Jaarsveld et al. (1984).

Twenty-two adult animals were subjected to serial blood sampling for the duration of anaesthesia. Blood samples (approximately $10 \mathrm{ml}$ ) were collected from the cephalic vein using multisample needles and venoject evacuated tubes. Blood was stored at $4^{\circ} \mathrm{C}$ until it was centrifuged for $10 \mathrm{~min}$ at $1000 \mathrm{~g}$. Serum was stored at $-20^{\circ} \mathrm{C}$ until assayed. Rectal temperature was monitored intermittently and, if temperature was falling, hot water bottles and solar blankets were provided. The other animals were only subjected to one-off sampling after immobilization.

\section{Prolactin radioimmunoassay}

Concentrations of serum prolactin were determined using a heterologous double-antibody radioimmunoassay kit (IM. 1061; Amersham Laboratories, Bucks, UK), as prolactin standards or pituitary glands of spotted hyaenas were unavailable. The assay uses ovine anti-human prolactin antiserum, human pituitary standards $(0,5,15,50,100$ and $200 \mathrm{ng} \mathrm{ml}^{-1}$ ) in human serum, ${ }^{125}$ I-labelled human prolactin and donkey anti-sheep gamma globulin as second antibody. All freeze-dried constituents were reconstituted to specified volumes using water distilled into glass. The incubation mixture consisted of reference preparations $(100 \mu \mathrm{l})$ or serum samples $(200 \mu \mathrm{l})$, antiserum $(100 \mu \mathrm{l})$ diluted to $5.5 \mathrm{ml}$ and ${ }^{125} \mathrm{I}$-labelled human prolactin (approximately 10000 c.p.m. in $100 \mu \mathrm{l}$ ). The mixture was then incubated at room temperature $\left( \pm 20^{\circ} \mathrm{C}\right)$ for $24 \mathrm{~h}$. Donkey anti-human gamma globulin $(1 \mathrm{ml}$ - second antibody) was then added and incubation continued at room temperature for $5 \mathrm{~min}$ before separation of bound and free hormone by centrifugation at room temperature $(1500 \mathrm{~g})$ for $15 \mathrm{~min}$. The free iodinated prolactin in the supernatant was decanted into scintillation vials and $4 \mathrm{ml}$ scintillation fluid (Scintillator 299 (mim; Packard Instrument Co., IL, USA) was added. Radioactivity was measured $4 \mathrm{~h}$ later for 2 min, using a Packard 1500 Tri-Carb scintillation counter (Packard Instrument Co., IL, USA). As no spotted hyaena standards were available, the prolactin concentrations were expressed as $\mathrm{ng}$ human prolactin equivalents $\mathrm{ml}^{-1}$ serum. Mathematical interpolation of recorded sample values against a standard curve was carried out using Securia ${ }_{M}$ Plus RIA/QC software (Packard Instrument Co., Downers Grove, UK) over the range 5-200 $\mathrm{ng} \mathrm{ml}^{-1}$. 
Prolactin status. Two indices of prolactin status were evaluated, namely, the initial sample irrespective of the time since immobilization, and the total prolactin response, represented by the area beneath the prolactin response curve from the time of immobilization for $90 \mathrm{~min}$, following the rationale of Brown et al. (1988).

Validation of prolactin assay. Three spotted hyaenas from the Kruger National Park were maintained on halothane for $4 \mathrm{~h}$ after immobilization with Zoletil. They were injected with $\mathrm{l} \mu \mathrm{g} \mathrm{kg}^{-1}$ luteinizing-hormone-releasing hormone (LHRH: Hoechst, Frankfurt, Germany) intravenously after $90 \mathrm{~min}$. Plasma samples for androstenedione determination were collected at intervals of about $15 \mathrm{~min}$ for the total duration of anaesthesia. Three spotted hyaenas from the National Zoological Gardens were immobilized with Zoletil and maintained on halothane for about $2 \mathrm{~h}$ on two occasions. During each of these extended immobilizations, the animals were injected intravenously with either bromocriptine ( $1 \mathrm{mg} \mathrm{kg}^{-1}$ body weight; Sandoz Products (Pty) Ltd, Randburg, S. Africa) or metoclopramide ( $1 \mathrm{mg} \mathrm{kg}^{-1}$ body weight; Beechams, Betchworth, Surrey, UK) after stabilizing for $30 \mathrm{~min}$.

Specificity. The method proved to be acceptable for measuring prolactin concentration in spotted hyaenas. The binding of ${ }^{125}$ I-labelled prolactin to the antiserum was displaced in a parallel manner by serial dilutions of serum from a mature male and a lactating female hyaena (Fig. 1a). The addition of $200 \mu \mathrm{l}$ serum from a male treated with bromocriptine to the standard curve did not affect the binding (Fig. la) and all samples were therefore assayed against the human standards. Measured concentrations of prolactin in serum were not affected by volume $(100-200 \mu \mathrm{l})$. The injection with LHRH had no significant effect on concentrations of serum prolactin (Fig. $1 \mathrm{~b}$ ), whereas androstenedione, the principal steroid secreted from the ovary after stimulation with LHRH (van Jaarsveid \& Skinner 1991b), showed a marked positive response (Fig. Ic).
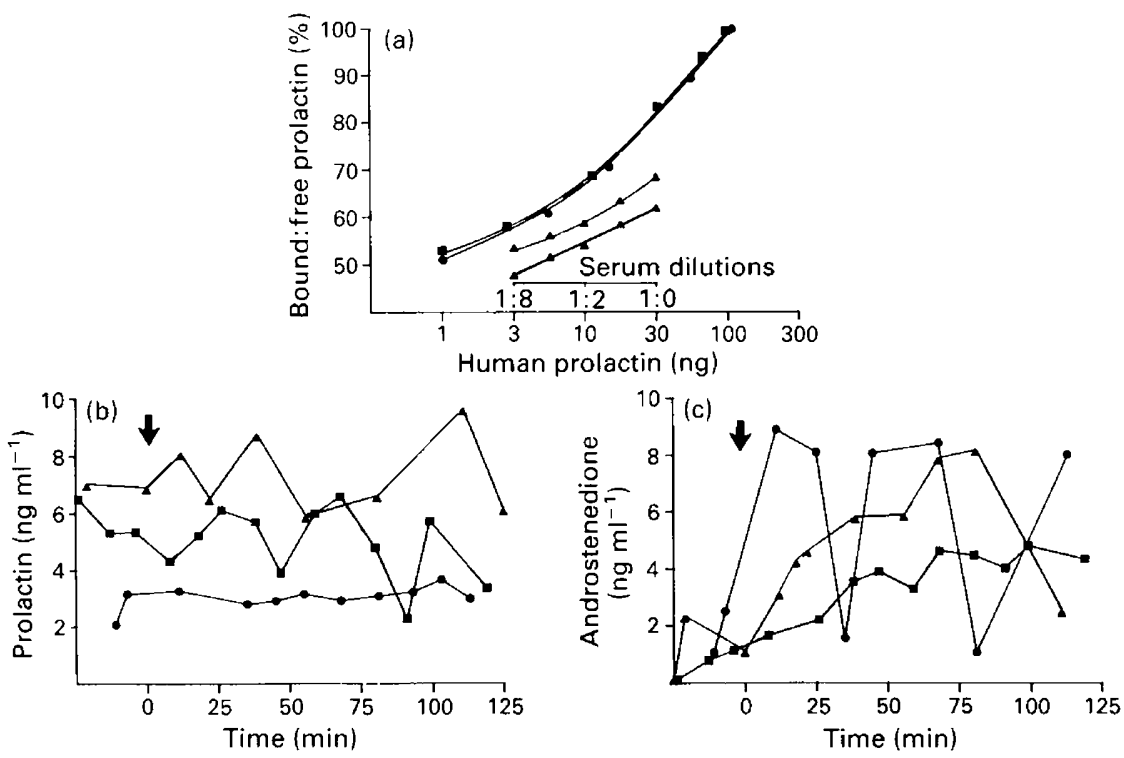

Fig. 1. (a) Standard curve for human prolactin prepared in distilled water ( $\mathbf{0})$ with and (O) without $200 \mu \mathrm{l}$ serum from a male spotted hyaena treated with bromocriptine and $(\boldsymbol{\Delta})$ doseresponse curves from dilutions of spotted hyaena serum; (b) concentrations of serum prolactin in three spotted hyaenas after an injection (arrow) of $1 \mu \mathrm{g}$ luteinizing-hormone-releasing hormone (LHRH) $\mathrm{kg}^{-1}$ body weight and (c) androstenedione responses from the ovary of three females after injection (arrow) with $1 \mu \mathrm{g} \mathrm{LHRH} \mathrm{kg}{ }^{-1}$ body weight.

Accuracy. The recovery of known amounts of human prolactin (15-100 ng) added to the serum of a spotted hyaena treated with bromocriptine did not differ significantly from expected values $\left(t_{2}=1 \cdot 81 ; P>0.2\right)$.

Sensitivity and precision. Sensitivity was $0.76 \pm 0.23 \mathrm{ng}$ prolactin $\mathrm{ml}^{-1}$ serum. The proportion of total radioactivity bound by the anti-serum in the absence of hormone ranged from 48.38 to $54.04 \%$. The intra- and interassay coefficients of variation were 2.04 and $14 \cdot 12 \%$, respectively.

Biological validation. All three treated spotted hyaenas showed a significant increase $\left(t_{31}=-37.39 ; P<0.01\right)$ in serum prolactin concentrations after the injection of metoclopramide, the effect being significantly greater in the immature male than in a nulliparous female and a mature male. A significant decrease $\left(t_{31}=-39 \cdot 65 ; P<0 \cdot 01\right)$ was seen after the injection of bromocriptine (Fig. 2). 

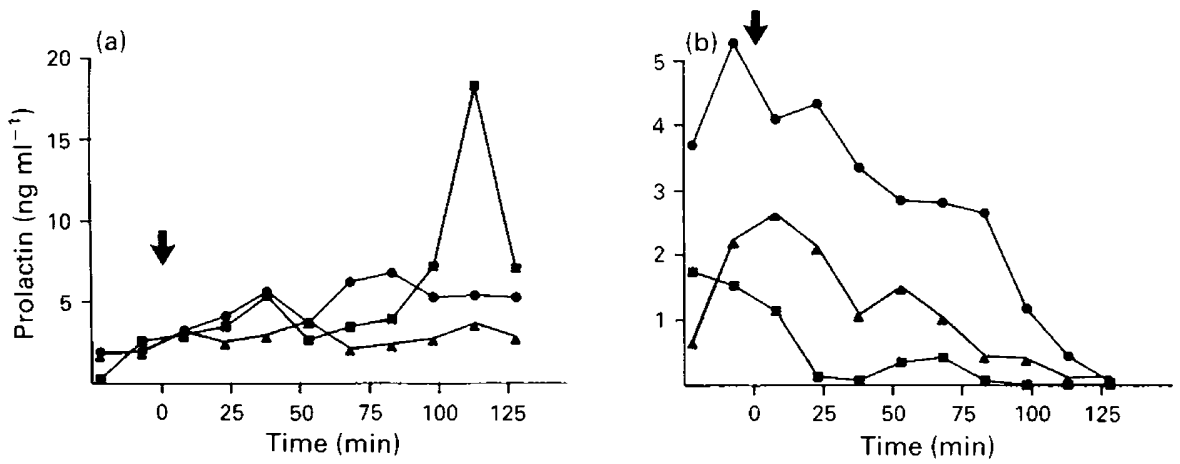

Fig. 2. Concentrations of serum prolactin in (O) mature and $(\boldsymbol{D})$ immature males and $(\boldsymbol{\Delta})$ a nulliparous female spotted hyaena after injection (arrow) with (a) metoclopramide and (b) bromocriptine ( $1 \mathrm{mg} \mathrm{kg}^{-1}$ body weight).

\section{Androstenedione radioimmunoassay}

Plasma androstenedione was assayed using the same chemical reagents, and following procedures described by van Jaarsveld \& Skinner (199lb). Plasma aliquots of $0.1 \mathrm{ml}$ were assayed using antisera raised in rabbits against androstenedione-7-hemisuccinate bovine serum albumin (Miles Yeda, Kiryat Weizman, Rehovot, Israel). Crossreactions with other steroids were $32 \%$ for 5 -androstane-3,17-dione, $3 \%$ for testosterone and dehydropiandrosterone, $0.6 \%$ for 11 -deoxycorticosterone and progesterone, $0.2 \%$ for oestrone and $<0.01 \%$ for oestradiol. Sensitivity of the assays ranged from 3.92 to $16.70 \mathrm{pg} \mathrm{ml}^{-1}(\bar{x}=5.98 \pm 3.63 \mathrm{sD} ; n=7)$. Intra- and interassay coefficients of variation were 7.31 and $5.28 \%$, respectively.

\section{Statistical analyses}

All statistical procedures used were in accordance with the statistical principles described by Sokal \& Rohlf (1980). Statistical manipulations were carried out using SAS Institute Inc. (Illinois, USA) software. The relevant procedures used are specified with the results. The frequency distributions of all data sets were tested for normality, and variances for homoscedasticity. When raw data failed to comply with the required criteria for parametric analyses, data transformations were used to obtain normality and/or homoscedasticity. When data sets or subsets still failed to comply with parametric criteria, nonparametric statistical procedures were used.

\section{Results}

Correlation analysis showed that there was a strong positive rank correlation (Spearman $-r_{\mathrm{s}}=$ $0.78 ; P<0.001 ; n=22$ ) between the initial sample and the total prolactin response (Fig. 3). In 12 $(55 \%)$ of the animals subjected to serial sampling, the highest prolactin concentrations recorded were the initial samples. Of the ten animals that showed subsequent increases, six $(27 \%)$ were represented by the lactating females in the sample, all of which tended to show a general increase after starting from low initial values (Fig. 3b). Other animals that showed subsequent increases in serum prolactin concentrations after the initial sample included two resident natal males (Fig. 3d), one peripheral immigrant male (Fig. 3e) and a parous female (Fig. 3a). This tendency to increase and decrease after the first sample showed no relationship to the time of first sampling, as individuals that showed an increase were, on average, first sampled after those that showed a decline $(\bar{x}=18.90 \mathrm{~min}$ compared with $\bar{x}=3.82 \mathrm{~min})$. Visual inspection of the profiles also showed that males generally displayed a larger variance than females in prolactin concentrations after immobilization stress.

The initial values were used as an index of prolactin status and a parametric ANOVA (PROC GLM) comparing $\log _{10}\left[\right.$ prolactin] showed no significant difference $\left(F_{0.05[1.55]}=4.60\right)$ between 
(a)

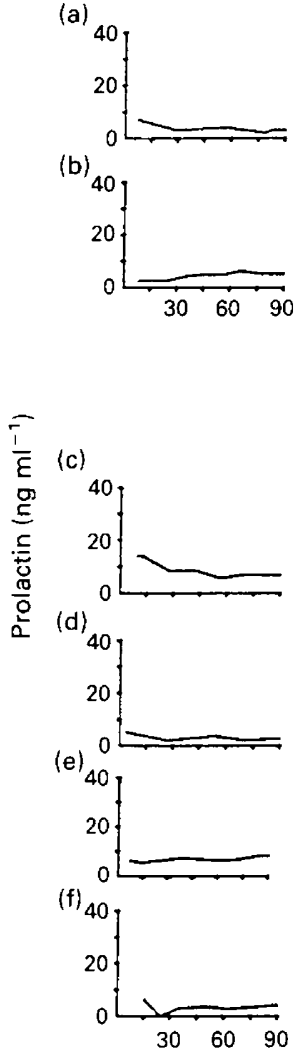

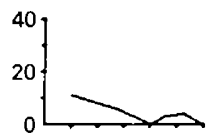
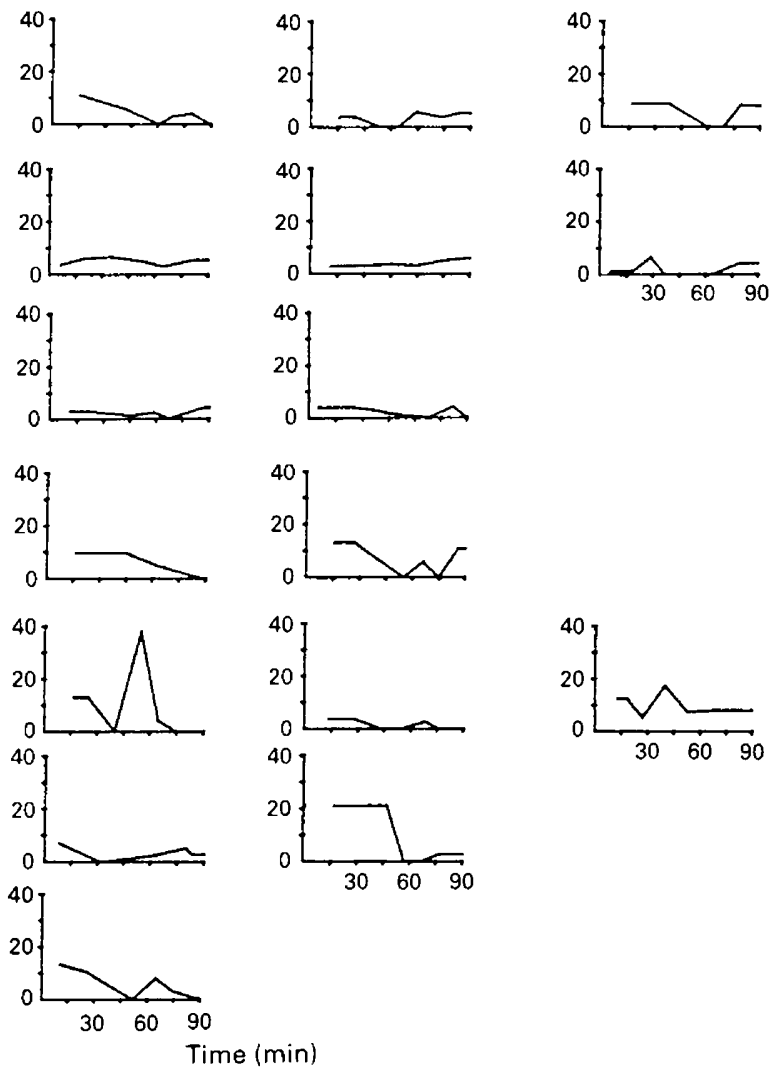

Fig. 3. Serum prolactin profiles from 22 spotted hyaenas immobilized with Zoletil and maintained for $90 \mathrm{~min}$ on halothane. (a) Parous females; (b) lactating females; (c) nulliparous females; (d) resident natal males; (e) peripheral immigrant males; and (f) central immigrant males.

sexes or with respect to the month of the year that samples were collected $\left(F_{0.05[11 \cdot 55]}=4 \cdot 52\right)$. This lack of a seasonal pattern is further supported by the presence of the highest and lowest recorded concentrations of serum prolactin in the same month (1.34 versus $50.80 \mathrm{ng} \mathrm{ml}^{-1}$ in November). A similar analysis for the various reproductive $\left(F_{0.05[4.55]}=15.79\right)$ and social $\left(F_{0.05[5.53]}=3.65\right)$ categories showed significant variation. A comparison of means revealed that lactating females had significantly lower $\left(\mathrm{HSD}_{51}=3.99 ; P<0.05\right)$ prolactin concentrations than animals in all the other reproductive categories. Parous females, however, showed a lower mean prolactin concentration than the remaining categories but the difference was not statistically significant (Fig. 4a). Among the social categories, the peripheral immigrant males, the male cubs and the female cubs had high mean prolactin concentrations, but these differences did not reach statistical significance, and only the male cubs had significantly higher $\left(\mathrm{HSD}_{48}=4 \cdot 197 ; P<0.05\right)$ mean titres than the resident females (Fig. 4b).

No significant difference was found between male and female cubs in mean serum prolactin concentrations (Fig. 4b) or in the observed trends during the first year of development (Fig. 5a, b). More important, however, is that there is an indication of reduced prolactin titres during this developmental phase, as was the case for cortisol (van Jaarsveld, 1990). Correlation analysis revealed a negative relationship between age and initial prolactin concentrations (Pearsons $-r=$ $-0.28 ; P<0.05 ; n=56$ ), reflecting the high prolactin concentrations observed in cubs (Fig. $4 \mathrm{~b}$ ). 

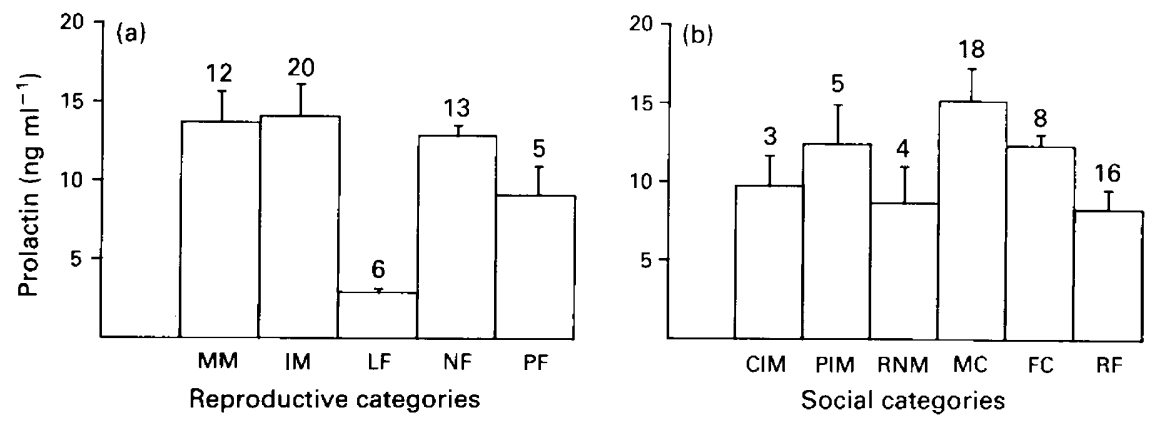

Fig. 4. Serum human prolactin equivalents (mean \pm SEM) for (a) reproductive categories: mature males (MM; >2 years), immature males (IM; $\leqslant 2$ years), lactating females (LF), nulliparous females (NF), parous females (PF) and (b) social categories: central immigrant males (CIM), peripheral immigrant males (PIM), resident natal males (RNM), male cubs (MC), female cubs (FC), and resident females (RF). ANOva was run on $\log _{10}$ [prolactin]. Statistical significance was measured at $P<0 \cdot 05$. Numbers above columns indicate sample size.

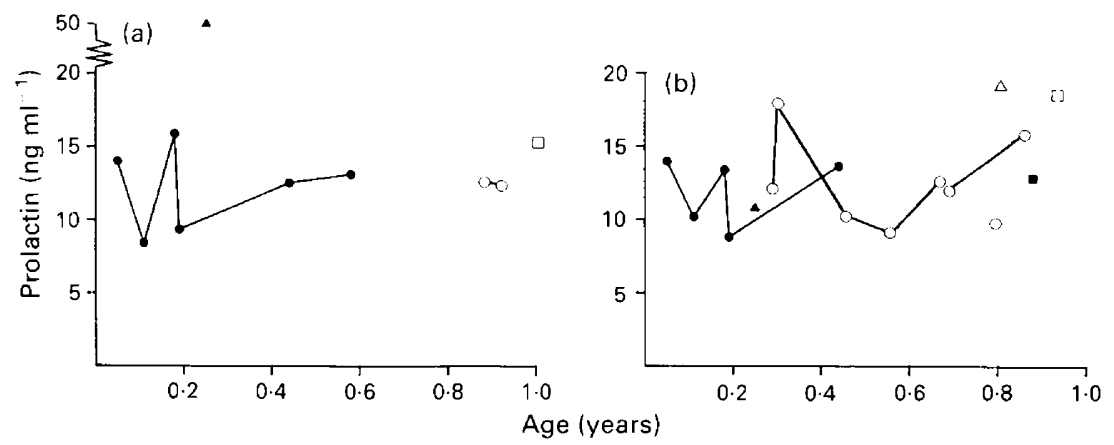

Fig. 5. Serum prolactin profiles for (a) female $(n=4)$ and (b) male $(n=7)$ spotted hyaena cubs. Different animals are represented by different symbols; serial samples from the same animals are connected.

\section{Discussion}

Although it is generally accepted that prolactin concentration increases during acute stress, this is not always the case; a decrease in circulating prolactin concentrations often occurs when concentrations have already been raised (Krieg et al., 1984; Gala \& Haisenlander, 1986), or during chronic stress (Collu et al., 1979; López-Calderon et al., 1989). Thus, the general trend of declining prolactin concentrations observed in animals subjected to serial sampling in this study suggests that some prolactin stress response to immobilization had already occurred by the time the first sample was collected. The mean time of first sampling for these serial samples was $20 \cdot 23 \mathrm{~min}$ and rats are known to show increased concentrations of prolactin $2045 \mathrm{~min}$ after immobilization stress (López-Calderon et al., 1989). The initial samples used in the present study therefore probably represent stress-induced concentrations rather than basal concentrations.

The lack of any significant increase in the initial prolactin concentrations in the dispersing peripheral immigrant males (Fig. 4b), which are usually at the bottom of the social hierarchy (Henschel \& Skinner, 1987), is similar to the pattern found for cortisol concentrations in plasma (van Jaarsveld, 1990). These data conform with earlier work on captive talapoin monkeys (Miopithecus talapoin) 
in which no correlation between male social rank and prolactin concentrations could be found (Yodingyuad et al., 1982). Although social status was not measured in this study, serum prolactin concentrations did not differ in dominance-related social categories, clearly reflecting the effects of social suppression on circulating concentrations of androgen in males (van Jaarsveld \& Skinner, 1991a).

A negative correlation between plasma cortisol and serum prolactin in mature male spotted hyaenas (van Jaarsveld, 1990) suggests that these hormones may act in a stress-related manner in this species. This relationship could indicate a negative feedback between adrenocortical activity and prolactin stress responsiveness, a process documented in rats (López-Calderon et al., 1989). On the other hand, it could be the result of the different control mechanisms of these stress-related hormones (Naylor et al., 1990), or that these hormones respond in different ways to social modifications and that they do not simply reflect a single intervening variable, such as stress (Eberhardt et al., 1985). Some support for the view that these hormones are regulated independently comes from the observation that the apparent cortisol stress nonresponsive period observed in juvenile spotted hyaenas (van Jaarsveld, 1990) is not accompanied by a change in prolactin-stress responsiveness. However, if prolactin primarily functions as a protective factor in stress-induced biological changes (Drago et al., 1989), high prolactin concentrations would complement the unperturbed concentrations of cortisol found during the cortisol stress nonresponsive period and ensure normal central nervous system and behavioural development of juvenile animals (Sapolsky \& Meaney, 1986). This line of reasoning and the observed negative relationship between these two hormones in adult males does not rule out a negative feedback relationship between cortisol and prolactin.

The similarity between the concentrations of prolactin in peripheral immigrant males and male and female cubs (Fig. 5) indicates a form of hyperprolactinaemia in dispersing males. These concentrations are similar to those found in prepubertal pigs (Sus scrofa) and blue foxes (Alopex lagopus) in seasonal anoestrus (Mondain-Monval et al., 1985; Smith et al., 1985). These high prolactin concentrations (about $12 \mathrm{ng} \mathrm{ml}^{-1}$ ) suggest that the testicular inactivity of dispersing males (van Jaarsveld \& Skinner, 1991) and the gonadal inactivity of prepubertal spotted hyaenas (Lindeque, 1981) may be correlated with hyperprolactinaemic conditions (McNeilly, 1980; Haynes \& Howles, 1981). The decline in mean serum prolactin titres observed in the resident natal males, between puberty and dispersion, is accompanied by a transition from the prepubertal to pubertal testis. In support of this view, the positive correlation recorded between prolactin and androstenedione concentrations in male cubs changes to a positive correlation between prolactin and testosterone in the resident natal males (van Jaarsveld, 1990).

Among the reproductive categories, lactating spotted hyaenas are prominent for their low serum prolactin concentrations (Fig. 4a). These low prolactin concentrations in lactating animals follow the pattern previously observed in rabbits (Oryctolagus cunniculus) and brown hares (Lepus europaeus) (McNeilly \& Friesen, 1978; Caillol et al., 1990). In contrast, prolactin concentrations are high for the duration of lactation in cats (Felis domesticus) (Banks et al., 1983) and blue foxes (Mondain-Monval et al., 1985). This species-specific difference has been attributed to differences in the suckling patterns; rabbits and hares suckle their young only once a day in contrast to the frequent suckling observed in cats (Caillol et al., 1990). Similarly, although spotted hyaena cubs depend on milk for 4-6 months and are not weaned until 14-18 months (East et al., 1989), the lactating females are often forced to move large distances in search of food and, consequently, mothers may be away from their cubs for up to 5 days (Kruuk, 1972; East et al., 1989). This results in an irregular and sometimes infrequent suckling pattern in this species. These reduced prolactin concentrations observed during lactation could explain previous reports concerning the lack of a distinct lactational anoestrus in this polyoestrous aseasonal breeder (Lindeque, 1981; Lindeque \& Skinner, 1982; Lindeque et al., 1986). Histological and endocrine data suggest that follicular development can be resumed during lactation or shortly thereafter in this species (van Jaarsveld et al., 1992) and provides a mechanism whereby spotted hyaenas, which usually produce only two pre- 
cocial young in each litter (van Jaarsveld et al., 1988) and have an extended lactation period (East $e t$ al., 1989), can significantly increase population recruitment rates. In support of this view, negative correlations between prolactin and progesterone in lactating females, and between prolactin and oestradiol in this species, suggest that prolactin secretion declines when ovarian activity increases (van Jaarsveld, 1990). This may also indicate feedback regulation of stress-induced prolactin by progesterone, as recorded in rats (Deis et al., 1989).

The Board of Trustees, National Parks Board of South Africa and the Director and staff of the National Zoological Gardens (Pretoria) are thanked for their co-operation on this project. A. van Jaarsveld received Senior Maberly memorial Scholarships from the Transvaal Branch of the Wildlife Society of Southern Africa and financial support from the Foundation for Research Development is gratefully acknowledged.

\section{References}

Banks, D.R., Paape, S.R. \& Stabenfeldt, G.H. (1983) Prolactin in the cat: 1 Pseudopregnancy, pregnancy and lactation. Biology of Reproduction 28, 923-932.

Brown, J.L., Goodrowe, K.L., Simmons, L.G., Armstrong, D.L. \& Wildt, D.E. (1988) Evaluation of the pituitarygonadal response to $\mathrm{GnRH}$, and adrenal status, in the leopard (Panthera pardus japonensis) and tiger (Panthera tigris). Journal of Reproduction and Fertility 82, 227-236.

Caillol, M., Mondain-Monval, M. \& McNeilly, A.S. (1990) Pattern of serum concentrations of prolactin and progesterone during pregnancy and lactation in the brown hare (Lepus europaeus). Journal of Endocrinology 124, 11-17.

Collu, R., Tache, Y. \& Ducharme, J.R. (1979) Hormonal modifications induced by chronic stress. Journal of Steroid Biochemistry 11, 989-1000.

Deis, R.P., Leguizamon, E. \& Jahn, G.A. (1989) Feedback regulation by progesterone of stress-induced prolactin release in rats. Journal of Endocrinology 120,37-43.

Drago, F., Agata, V.D., Iacona, T., Spadaro, F., Grassi, M., Valerio, C., Raffaele, R., Astuto, C., Lauria, N. \& Vitetta, M. (1989) Prolactin as a protective factor in stress-induced biological change. Journal of Clinical and Laboratory Analysis 3, 340-344.

East, M., Hofer, H. \& Turk, A. (1989) Functions of birth dens in spotted hyaenas (Crocuta crocuta). Journal of Zoology, London 219, 690-697.

Eberhart, J.A., Keverne, E.B. \& Meller, R.E. (1983) Social influences on circulating levels of cortisol and prolactin in male talapoin monkeys. Physiology and Behaviour 30, 361-369.

Eberhart, J.A., Yodyingyuad, U. \& Keverne, E.B. (1985) Subordination in male talapoin monkeys lowers sexual behaviour in the absence of dominance. Physiology and Behaviour 35, 637-677.

Frank, L.G. (1983) Reproduction and intra-sexual dominance in the spotted hyaena (Crocuta crocuta). $\mathrm{PhD}$ thesis, University of California, Berkeley.

Frank, L.G. (1986) Social organization of the spotted hyaena (Crocuta crocuta). II. Dominance and reproduction. Animal Behaviour 34, 1510-1527.

Gala, R.R. \& Haisenleder, D.J. (1986) Restraint stress decreases afternoon plasma prolactin levels in female rats. Influence of neural antagonist and agonist on restraint-induced changes in plasma prolactin and corticosterone. Neuroendocrinology 43, 115-123.

Golding, R.R. (1969) Birth and development of spotted hyaenas at the University of Ibadan Zoo, Nigeria. International Zoo Yearbook 9, 93-95.

Grimpe, G. (1916) Hyänologische Studen. Zoologische Anzen 48, 49-61.

Haynes, N.B. \& Howles, C.M. (1981) The environment and reproduction. In Environmental aspects of housing for animal production, pp. 63-83. Ed. J. A. Clark. Butterworth, London.

Henschel, J.R. (1986) The socio-ecology of a spotted hyaena Crocuta crocuta clan in the Kruger National Park. DSc thesis, University of Pretoria.

Henschel, J.R. \& Skinner, J.D. (1987) Social relationships and dispersal patterns in a clan of spotted hyaenas Crocuta crocuta in the Kruger National Park. South African Journal of Zoology 22, 18-24.

Henschel, J.R. \& Skinner, J.D. ( [990) Parturition and early maternal care of spotted hyaenas Crocuta crocuta: a case report. Journal of Zoology, London 222, 702-704.

Henschel, J.R. \& Skinner, J.D. (1991) Territorial behaviour by a clan of spotted hyaenas Crocuta crocuta. Ethology 88, 223-235.

Krieg, R.J., Lamberts, S.W.J. \& Macleod, R.M. (1984) Paradoxical suppression of prolactin secretion: involvement of catecholaminergic mechanism of the adrenal gland. Acta Endocrinologica 105, 463-467.

Kruuk, H. (1972) The spotted hyena: a study of predation and social behavior. Chicago University Press.

Lindeque, M. (1981) Reproduction in the spotted hyaena Crocuta crocuta (Er.xleben). MSc thesis. University of Pretoria.

Lindeque, M. \& Skinner, J.D. (1982) Aseasonal breeding in the spotted hyaena (Crocuta crocuta, Erxleben), in southern Africa. African Journal of Ecology 20, 271278.

Lindeque, M., Skinner, J.D. \& Miller, R.P. (1986) Adrenal and gonadal contribution to circulating androgens in spotted hyaenas (Crocuta crocuta) as revealed by LHRH, hCG and ACTH stimulation. Journal of Reproduction and Fertility 78, 211-217.

López-Calderon, A., Ariznavaretta, C., Calderon, M.D., Tresguerres, J.A.F. \& Gonzalez-Quijano, M.I. (1989) Role of the adrenal cortex in chronic stress-induced 
inhibition of prolactin secretion in male rats. Journal of Endocrinology 120, 169-173.

McNeilly, A.S. (1980) Prolactin and the control of gonadotrophin secretion in the female. Journal of Reproduction and Fertility 58, 537-549.

McNeilly, A.S. (1987) Prolactin and the control of gonadotrophin secretion. Journal of Endocrinology 115, 1-5.

McNeilly, A.S. \& Friesen, H.G. (1978) Prolactin during pregnancy and lactation in the rabbit. Endocrinology 102, 1548-1554.

Matthews, L.H. (1939) Reproduction in the spotted hyaena Crocuta crocuta (Erxleben). Philosophical Transactions of the Royal Society of London Series $B$ 230, 180.

Mills, M.G.L. (1985) Related spotted hyaenas forage. together but do not cooperate in rearing their young. Nature 316, 61-62.

Mondain-Monval, M., Moller, O.M., Smith, A.J., McNeilly, A.S. \& Scholler, R. (1985) Seasonal variations of prolactin and LH concentrations in the female blue fox (Alopex lagopus). Journal of Reproduction and Fertility 74, 439-448.

Naylor, A.M., Porter, D.W.F. \& Lincoln, D.W. (1990) Central administration of corticotrophin-releasing factor in the sheep: effects on secretion of gonadotrophins, prolactin and cortisol. Journal of Endocrinology 124, 117-125.

Sapolsky, R.M. \& Meaney, M.J. (1986) Maturation of the adrenocortical stress response: neuroendocrine control mechanisms and the stress hyporesponsive period. Brain Research Reviens 11, 65-76.

Schneider, K.M. (1926) Über Hyänenzucht. Peltztierzucht 2, $12-14$.

Smith, A.J., Mondain-Monval, M., Moller, O.M., Scholler, R. \& Hansson, V. (1985) Seasonal variations of LH, prolactin, androstenedione, testosterone, and testicular FSH binding in the male blue fox (Alopex lagopus). Journal of Reproduction and Fertility 74, 449-458.

Sokal, R.R. \& Rohlf, F.J. (1981) Biometry. W.H. Freeman, San Francisco. van Jaarsveld, A.S. (1988) The use of Zoletil for the immobilization of spotted hyaenas. South African Journal of Wildlife Research 18, 65-66.

van Jaarsveld, A.S. (1990) Endocrine Correlates of Social Development in the Spotted Hyaena Crocuta crocuta (Erxleben). PhD thesis, University of Pretoria.

van Jaarsveld, A.S. \& Skinner, J.D. (1991a) Plasma androgens in spotted hyaenas (Crocuta crocuta): influence of social and reproductive development. Journal of Reproduction and Fertility 93, 195-201.

van Jaarsveld, A.S. \& Skinner, J.D. (1991b) Plasma androgen titres in initial samples from spotted hyaenas immobilised with Zoletil (CI-744) reflect hormonal status estimated by GnRH challenge and immobilisation stress response. South African Journal of Zoology 26, 1-5.

van Jaarsveld, A.S., McKenzie, A.A. \& Meltzer, D.G.A. (1984) Immobilization and anaesthesia of spotted hyaenas, Crocuta crocuta. South African Journal of Wildlife Research 14, 120-122.

van Jaarsveld, A.S., Henschel, J.R. \& Skinner, J.D. (1987) Improved age estimation in spotted hyaenas (Crocuta crocuta). Journal of Zoology, London 213, $758-762$.

van Jaarsveld, A.S., Skinner, J.D. \& Lindeque, M. (1988) Growth, development and parental investment in the spotted hyaena, Crocuta crocuta. Journal of Zoology, London 216, 45-53.

van Jaarsveld, A.S., Lindeque, M. \& Skinner, J.D. (1992) Morphological and steroidogenic assessment of ovarian activity during lactation in the spotted hyaena (Crocuta crocuta). Journal of Zoology, London 226, 31-46.

Yodyingyuad, U., Eberhart, J.A. \& Keverne, E.B. (1982) Effects of rank and novel females on behaviour and hormones in talapoin monkeys. Physiology and Behaviour 28, 995-1005. 